\title{
EXPLORING THE CONCEPT OF REFLECTIVE PRACTICE IN THE CONTEXT OF STUDENT- CENTERED TEACHER EDUCATION
}

\author{
Remigijus Bubnys \\ Department of Education and Social Welfare, Šiauliai University, Lithuania \\ Loreta Zavadskienè \\ Department of Education and Social Welfare, Šiauliai University, Lithuania
}

\begin{abstract}
Being one of the most popular theories of professional knowledge in the last 30 years, reflective practice has been widely adopted not only by practicing teachers in their working environment, but in pre-service teacher education as well. Meeting the need to respond to the challenges posed by the society nowadays, higher education is undergoing radical changes calling for the proper implementation of student-centered studies. In the context of such a paradigm shift there is a strong urge for the concept of reflective practice to be examined more carefully so that it could be put into effect in the studies of higher education. The paper seeks to respond to this problem by offering an in-depth analysis of the attributes characteristic of the concept of reflective practice in the paradigm shift. Based on the thorough review of scientific works dealing with the concept of reflective practice in teacher education, the current study reports on the insights regarding the development of this concept for reflective practice to be successfully applied in the process of teacher education.
\end{abstract}

Keywords: reflective practice, student-centered studies, pre-service teachers, higher education.

\section{Introduction}

The term reflective practice has become common within the discourse of teacher education and is widely acknowledged as an essential component in the professional development of student teachers. The need for its embedment in study programmes of pre-service teacher education is dictated by the transformations higher education institutions are experiencing nowadays. Meeting the need to respond to the challenges posed by the society, higher education is undergoing radical changes calling for the proper implementation of student-centered studies that put reflective practice at their heart. This demand is supported by one of the most important goals of higher education to develop students' ability to learn continuously, reflecting on one's experience, in order to develop prospective specialists' holistic competence (Jakubè \& Juozaitis, 2012). The capacity to reflect is recognised as one of the main generic competences and 
is of high importance in the context of pre-service teacher education as well, since it encompasses the need for student teachers not only to be able to reflect on their learning process while acquiring their professional knowledge, but is also directly related to their future careers. Being one of the most popular theories of professional knowledge in the last 30 years, reflective practice has been widely adopted not only by practicing teachers in their working environment, but in preservice teacher education as well. In the context of a paradigm shift there is a strong urge for the concept of reflective practice to be examined more carefully so that it could be put into effect in the studies of higher education. Therefore, the purpose of this article is to explore how reflective practice has been conceptualized in teacher education and is to be promoted within the professional landscape of pre-service teacher education in the student-centered studies. This paper aims: (1) to examine the concept of reflective practice in relation to teacher education by providing an overview of major meanings proposed by influential educationalists and (2) to investigate into the manifestation of reflective practice in the context of student-centered studies in pre-service teacher education.

\section{Research Methodology}

\section{Sample}

The selection of scientific literature resources for this research paper was criterion-based. The criteria were the following: (1) the resource had to be scientific (based on research or conceptual evidence and published as an article, monograph, $\mathrm{PhD}$ dissertation or a research report); (2) the keywords for selection were reflective practice, student-centered studies, pre-service teacher education; (3) the resource could have been written in the Lithuanian or English languages.

\section{Method}

The current research paper employs the method of literature review which is an account of what has been published on a topic by accredited scholars and researchers (Taylor, 2010). In writing the literature review, the purpose is to convey to the reader what knowledge and ideas have been established on a topic. As a piece of writing, the literature review is defined by a guiding concept (e.g., research aim, the problem the author discusses). The performed steps of the literature review were as follows: (1) organizing the literature selection and review by relating it directly to the research question the authors develop; (2) synthesizing results into a summary of what is and is not known; (3) identifying areas of controversy in the literature. 


\section{The multi-faceted nature of reflective practice}

The term of reflective practice, deriving from the works of John Dewey and Donald Schön, has received considerable attention of theorists and practitioners in teacher education. Yet, despite its popularity and widespread adoption, a problem frequently raised in the literature concerns the lack of conceptual clarity surrounding the term of reflective practice (Finlay, 2009).

The concept of reflective practice can be described as "phenomenological, in that a given phenomenon is studied through direct experience, interpreted and the insights gained used, to further understanding and modify actions" (Zwozdiak-Myers, 2009, p. 9).

Driven by the goal to better understand key characteristics theorists, practitioners and researchers within pre-service teacher education associate with reflective practice, this paper examines and draws together the central understandings underpinning the concept of reflective practice that have emerged chronologically.

Although the roots of reflective practice can be traced back to ancient times, the theoretical foundations for it were laid at the beginning of the $20^{\text {th }}$ century. J.Dewey was among the first to write about reflective practice with his exploration of experience, interaction and reflection. He explained reflection in terms of reflective thought defining it as "the active, persistent and careful consideration of any belief or supposed form of knowledge in light of the grounds that support it" (Dewey, 1933, p. 7) and identified five phases or states of reflective thinking: problem, suggestions, reasoning, hypothesis, testing. The three attitudes, such as openmindedness, responsibility, wholeheartedness, according to him, are integral to reflective action and are necessary for teaching and learning (Dewey, 1933). His assertion that learning results from the act of making sense of experience (reflection) (Dewey, 1938), highlights the need for schooling to be based in experience so that learners are to be provided with experiences that would cause and give direction to their growth (Rodgers \& LaBoskey, 2016, p. 75). As the ultimate purpose of education Dewey considered to be the ongoing creation of a vibrant and responsible democracy (ibid).

J. Habermas (1971) focused on the way in which humans process ideas and construct them into knowledge and recognized that reflection plays a role in this process. He talked about three kinds of knowledge: - instrumental (needed to understand, function within and control human environment); - interpretive (concerned with the interpretation of human action and behaviour); - emancipatory/transformational (developed through critical or evaluative modes of thinking and leading towards the emancipation or transformation of personal, social or other situations). 
M. van Manen's (1977) contribution to a better understanding of various aims of reflection was in his development of a hierarchy of three levels of reflectivity: • technical rationality (implying the focus on methodology and theory development to achieve objectives); • practical application or contextual (related to pragmatic placement of theory into practice); $\bullet$ critical reflection or dialectical (to be understood as value commitment toward educational process).

D. Schön (1983) introduced the concept of the 'reflective practitioner' as one who uses reflection as a tool for revisiting experience. In his theory of reflective practice he identified two types of reflection: reflection-on-action (thinking after the event), during which professionals consciously review, describe and evaluate their past practice gaining at the same time the insight how future practice could be improved; and reflection-in-action (thinking while doing) that allows professionals to explore their experiences and responses as they occur.

D. Kolb (1984) is well known for his development of the cycle of experiential learning, which considers reflecting as an essential element of learning, and is currently widely spread and applied to the practice of higher education. Learning is perceived as a four-stage cycle: - concrete experience; - reflective observation; $\bullet$ abstract conceptualization; $\bullet$ active experimentation.

D. Boud, R. Keogh and D. Walker (1985) describe a model of reflection in the learning process, which encompasses the cycle of: • association; $\bullet$ integration; - validation; • appropriation. It begins with the "totality of experiences of learners" (p. 20), including their behaviour, ideas and feelings. This model provides more insight than Kolb's learning cycle, but is missing the context surrounding the learner, an important element of the process.

F. Korthagen (1985) devised a model known as ALACT to support systemic reflection process which is a suitable frame for enhancing the reflection of teachers and consists of five phases: - action; - looking back at the action; - becoming aware of the essential aspects; $\bullet$ creating alternative methods of action; - trial of the alternative methods of action, which itself is a new action and therefore the starting point of a new cycle.

The assertions made by the authors discussed above have laid the basis for further interpretations and development of the reflective practice concept. As careful literature review shows, since 1990 the interest in reflective practice has remained constant. The information embracing the contributions made by different theoreticians and practitioners to the concept of reflective practice are introduced in Table 1, identifying the proponents, their main focus and terminology embedded within each theme. 
Table 1 Concepts related to reflective practice in teacher education

\begin{tabular}{|c|c|c|}
\hline Proponent & Focus & Themes \\
\hline $\begin{array}{l}\text { Grimmett, } \\
\text { MacKinnon, } \\
\text { Erickson, \& } \\
\text { Riechen (1990) }\end{array}$ & $\begin{array}{l}\text { Levels of reflective } \\
\text { teaching }\end{array}$ & $\begin{array}{l}\text { Technical: instrumental mediation of actions } \\
\text { Deliberative: deliberation among competing } \\
\text { views } \\
\text { Dialectical: reconstruction of experience }\end{array}$ \\
\hline Valli (1990) & Images of teaching & $\begin{array}{l}\text { Technical rationality: non-reflective } \\
\text { Practical decision-making: technical within a } \\
\text { reflective context } \\
\text { Inculcation, indoctrination: moral, ethical \& } \\
\text { social in a non-reflective mode } \\
\text { Moral reflection: deliberative, relational, } \\
\text { critical }\end{array}$ \\
\hline $\begin{array}{l}\text { Killion \& Todnem } \\
\text { (1991) }\end{array}$ & Types of reflection & $\begin{array}{l}\text { Reflection-on-action (thinking about action) } \\
\text { Reflection-in-action (reflecting during action) } \\
\text { Reflection-for-action (thought then action } \\
\text { follows) }\end{array}$ \\
\hline Ross (1990) & $\begin{array}{l}\text { Categories of } \\
\text { teaching reflection }\end{array}$ & $\begin{array}{l}\text { Recognizing an educational dilemma; } \\
\text { responding to a dilemma; framing and } \\
\text { reframing the dilemma; experimenting with the } \\
\text { dilemma; considering intended and unintended } \\
\text { consequences }\end{array}$ \\
\hline $\begin{array}{l}\text { Sparks-Langer \& } \\
\text { Colton (1991) }\end{array}$ & $\begin{array}{l}\text { Orientations to } \\
\text { reflective thinking }\end{array}$ & Cognitive, narrative, critical \\
\hline Mezirow (1991) & Levels of reflection & $\begin{array}{l}\text { Non-reflective action; habitual action; } \\
\text { thoughtful action; introspection; reflective } \\
\text { action: content, process, and premise }\end{array}$ \\
\hline $\begin{array}{l}\text { Colton \& Sparks- } \\
\text { Langer (1993) }\end{array}$ & $\begin{array}{l}\text { A framework for } \\
\text { developing teacher } \\
\text { reflection }\end{array}$ & $\begin{array}{l}\text { Building a professional knowledge base; } \\
\text { developing an action to plan, implementing it } \\
\text { and evaluating instruction; providing } \\
\text { opportunities for constructing new meaning; } \\
\text { developing attributes of reflective decision- } \\
\text { making }\end{array}$ \\
\hline LaBoskey (1994) & $\begin{array}{l}\text { Types of reflective } \\
\text { thinkers }\end{array}$ & $\begin{array}{l}\text { Common sense thinkers - Alert novices - } \\
\text { Pedagogical thinkers }\end{array}$ \\
\hline $\begin{array}{l}\text { King \& Kitchener } \\
\text { (1994) }\end{array}$ & $\begin{array}{l}\text { Model of reflective } \\
\text { judgement }\end{array}$ & $\begin{array}{l}\text { Pre-reflective reasoning (stages 1-3) } \\
\text { Quasi-reflective reasoning (stages } 4 \text { \& 5) } \\
\text { Reflective reasoning (stages } 6 \& 7 \text { ) }\end{array}$ \\
\hline $\begin{array}{l}\text { Hatton and Smith } \\
\text { (1995) }\end{array}$ & Types of reflection & $\begin{array}{l}\text { Descriptive information, descriptive reflection, } \\
\text { dialogic, critical reflection }\end{array}$ \\
\hline $\begin{array}{l}\text { Zeichner and } \\
\text { Liston (1996) }\end{array}$ & $\begin{array}{l}\text { Categories of } \\
\text { reflection }\end{array}$ & $\begin{array}{l}\text { Academic, social efficiency, developmentalist, } \\
\text { social reconstructive, generic }\end{array}$ \\
\hline Barnett (1997) & $\begin{array}{l}\text { Critical reflection: } \\
\text { political-social } \\
\text { dimensions }\end{array}$ & Action, self-reflection and understanding \\
\hline
\end{tabular}


Remigijus Bubnys, Loreta Zavadskiene. Exploring the Concept of Reflective Practice in the Context of Student-Centered Teacher Education

\begin{tabular}{|c|c|c|}
\hline Valli (1997) & $\begin{array}{l}\text { A hierarchy of } \\
\text { types of reflection }\end{array}$ & $\begin{array}{l}\text { Technical, reflection in/on action, deliberative, } \\
\text { personalistic, critical }\end{array}$ \\
\hline $\begin{array}{l}\text { Ghaye \& Ghaye } \\
\text { (1998) }\end{array}$ & $\begin{array}{l}\text { Reflective } \\
\text { conversations }\end{array}$ & $\begin{array}{l}\text { Descriptive, perceptive, receptive, interpretive, } \\
\text { critical }\end{array}$ \\
\hline Moon (1999) & Critical thinking & Reflexivity, metacognition \\
\hline $\begin{array}{l}\text { Baxter Magolda } \\
\text { (1999) }\end{array}$ & $\begin{array}{l}\text { Epistemological } \\
\text { cognition }\end{array}$ & Dualist position - Relativist position \\
\hline Lee (2000) & $\begin{array}{l}\text { Depth of reflective } \\
\text { thinking }\end{array}$ & Recall, rationalization, reflectivity \\
\hline $\begin{array}{l}\text { Jay \& Johnson } \\
(2002)\end{array}$ & $\begin{array}{l}\text { Dimensions of } \\
\text { reflection }\end{array}$ & Descriptive, comparative, critical \\
\hline $\begin{array}{l}\text { Grushka, Hinde- } \\
\text { McLeod, \& } \\
\text { Reynolds (2005) } \\
\end{array}$ & Types of reflection & $\begin{array}{l}\text { Reflection for action, reflection in action, } \\
\text { reflection on action }\end{array}$ \\
\hline $\begin{array}{l}\text { Korthagen \& } \\
\text { Vasalos (2005) }\end{array}$ & $\begin{array}{l}\text { Phase model of } \\
\text { core reflection }\end{array}$ & $\begin{array}{l}\text { Experience/problematic situation; awareness of } \\
\text { ideal situation/awareness of limitations; } \\
\text { awareness of core qualities; actualization of } \\
\text { core qualities; experimenting with new } \\
\text { behaviour }\end{array}$ \\
\hline Larrivee (2008) & Levels of reflection & $\begin{array}{l}\text { Pre-reflection, surface reflection, pedagogical } \\
\text { reflection, critical reflection }\end{array}$ \\
\hline $\begin{array}{l}\text { Thorsen \& } \\
\text { DeVore (2012) }\end{array}$ & $\begin{array}{l}\text { Developmental } \\
\text { Continuum of } \\
\text { Reflection-on/for- } \\
\text { Action Rubric } \\
\text { (DCRo/fA Rubric) }\end{array}$ & $\begin{array}{l}\text { Analyzing teacher candidates' indicators of } \\
\text { reflective thinking, reflective communication, } \\
\text { and cognitive processes; reflective practices as } \\
\text { continuum }\end{array}$ \\
\hline Liu (2015) & $\begin{array}{l}\text { Model of } \\
\text { transformative } \\
\text { learning }\end{array}$ & $\begin{array}{l}\text { Assumption analysis, contextual awareness, } \\
\text { imaginative speculation, reflective skepticism, } \\
\text { reflection-based actions, reflect on the effect- } \\
\text { based actions }\end{array}$ \\
\hline
\end{tabular}

Adapted from Zwozdiak-Myers (2009: 11) and renewed by the paper authors

Referring to the data in Table 1 it could be summarised that multiple perspectives the concept of reflective practice has been approached in the last three decades on the one hand clearly demonstrate its complexity, on the other hand, they underpin its importance within the domain of teacher education. Consequently, the attributes characteristic of reflective practice must be taken into account when applying the concept of reflective practice in all its possible forms and in all its relevant contexts. This argument leads to further investigations into how reflective practice is positioned and manifests itself in the context of studentcentered studies of pre-service teacher education. 


\section{Reflective practice in student-centered studies of pre-service teacher education}

Over the past century, strong educational movements, mainly conditioned by the changes in society, have occurred in higher education resulting in the need for higher education institutions to recognise a new paradigm to be implemented in the studies they provide, i.e. to shift away from an emphasis on teaching to an emphasis on learning. In essence, this paradigm change is founded on the assumption that students should be actively constructing and reconstructing knowledge in order to learn effectively, with learning being most effective when, as part of an activity, the learner experiences constructing a meaningful product. This is primarily grounded in the constructivist view of learning (Landau, 2001, p. 22). The shift from teaching to an emphasis on learning means that there has been a parallel shift in power away from the teacher to the student (Barr \& Tagg, 1995). While approaching a new teaching-learning paradigm, the term commonly used in the educational literature is student-centered learning (SCL). The main principles proposed by Lea et al. (2003), which underlie the concept of SCL, are summarised in Figure 2.

Closer examination of both the concept of SCL and reflective practice leads to the assumption that they correlate to a great extent and are interdependent: reflection on practice is a prerequisite for the quality of the new teaching/learning process. Further discussion attempts to support this assertion.

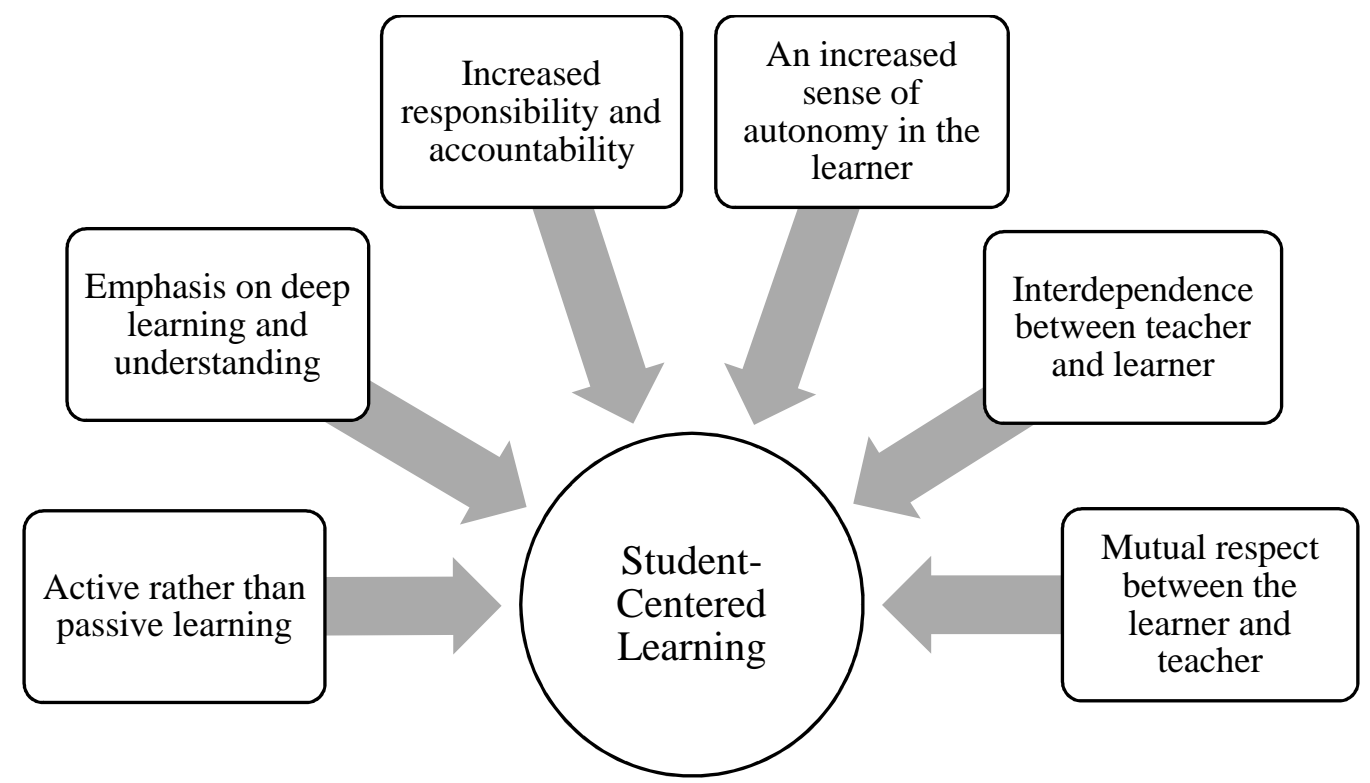

Figure 2 The concept of SCL (Designed by the paper authors)

The term reflective practice implies the nexus between reflection and practice. In pre-service teacher preparation programmes students of teaching are 
to (1) develop knowledge and skills of teaching and (2) to learn how to competently apply these in practice. Consequently, if the term practice encompasses both the practice of teaching and the practice of learning, then practical experience becomes a site for learning (Smith, 2005). The importance of reflective practice in pre-service education is grounded in the need for teacher students to learn the skills and dispositions of reflective inquiry so that they in turn can teach such ways of thinking to their students (Rodgers \& LaBoskey, 2016, p. 71). Such a proposition puts reflection on practice central to learning and development of knowledge required in the future profession and is highly resonant with increased responsibility and accountability, the principle underpinning the SCL concept.

Based on Dewey's ideas about reflection, Rodgers (2002) proposes four criteria for reflection which are relevant to contemporary education and can be applied to the understanding and promotion of reflective practices in pre-service teacher education:

- Reflection is a meaning-making process that moves a learner from one experience into the next with deeper understanding of its relationships with and connections to other experiences and ideas. It is the thread that makes continuity of learning possible, and ensures the progress of the individual and, ultimately, society. It is a means to essentially moral ends.

- Reflection is a systematic, rigorous, disciplined way of thinking, with its roots in system inquiry.

- Reflection needs to happen in community, in interaction with others.

- Reflection requires attitudes that value the personal and intellectual growth of oneself and of others (p. 845).

As for SCL, it is supposed to be a deep learning, which means that learning results have to be personally meaningful and significant and this can be achieved by employing reflective methods in education.

The assertion of SCL as being "characterised by innovative methods of teaching which aim to promote learning in communication with teachers and other learners and which take students seriously as active participants in their own learning, fostering transferable skills such as problem-solving, critical thinking and reflective thinking" ("Student-Centred Learning-Toolkit for students, staff and higher education institutions", 2010, p. 5), justifies further considerations relevant to the assumptions underlying the development of reflective practice that student teachers must be engaged in activities that will teach them how to go about reflecting. This argument puts a demand on teacher educators to choose the most relevant teaching in order to nurture and model 
effective and meaningful reflection. Finlay (2008, p. 16) identifies four guiding principles to be born in mind by educators:

- $\quad$ reflective practice(s) should be presented with care;

- adequate support, time, resources, opportunities and methods for refection should be provided;

- $\quad$ skills of critical analysis should be developed;

- $\quad$ proper account of the context of reflection should be taken.

These afore-mentioned principles enable educators to foster interdependence between teacher and learner and are built on mutual respect between them.

Summing up this part of the research paper, by now it should be evident that reflective practice and student-centered studies are underpinned by the same fundamental principles, putting reflection at their heart which, supported by proper teaching/learning practice, becomes a key aspect of lifelong learning.

\section{Conclusion}

The concept of reflective practice in the context of teacher preparation remains to be one of the most important issues which is constantly approached and researched by a wide array of theorists, practitioners and researchers in the field of higher education. It is multifaceted and complex and embraces different theories, categories, levels, types, frameworks, dimensions and models of reflection to be carefully considered when applying them in pre-service teacher education programmes.

The concept of reflective practice is embedded in student-centered studies of pre-service teacher higher education and is built on the same principles, the ultimate goal of which is to enable the process of transformation, first of all, of student teachers who will, in turn, make changes to the whole society.

\section{References}

Barnett, R. (1997). Higher Education: A Critical Business. Buckingham: Open University Press.

Barr, R. B., \& Tagg, J. (1995). From teaching to learning - a new paradigm for undergraduate education. Change Magazine, 27 (6): 12-25.

Baxter Magolda, M. (1992). Knowing and Reasoning in College Students. San Francisco: Jossey Bass.

Boud, D., Keogh, R., \& Walker, D. (1985). Promoting reflection in learning: a model. In D. Boud, R. Keogh \& D. Walker (Ed.), Reflection: Turning Experience into Learning. London: Kogan Page.

Colton, A. B., \& Sparks-Langer, G. M. (1993). A conceptual framework to guide the development of teacher reflection and decision making. Journal of Teacher Education, 44 (1), 45-54. http://dx.doi.org/10.1177/0022487193044001007 
Remigijus Bubnys, Loreta Zavadskiene. Exploring the Concept of Reflective Practice in the Context of Student-Centered Teacher Education

Dewey, J. (1933). How we Think: A Restatement of the Relation of Reflective Thinking to the Educative Process. Boston: DC Heath and Company.

Dewey, J. (1938). Experience \& Education. New York, NY: Kappa Delta Pi.

European Students Union (ESU). 2010. Student Centered Learning. Toolkit for students, staff and higher education institutions. Brussels. http://www.esib.org/documents/ publications/SCL_toolkit_ESU_EI.pdf

Finlay, L. (2008). Reflecting on 'Reflective practice'. Retrieved from http://www.open.ac.uk/ opencetl/files/opencetl/file/ecms/web-content/Finlay-(2008)-Reflecting-on-reflectivepractice-PBPL-paper-52.pdf

Ghaye, A., \& Ghaye, K. (1998). Teaching and learning through critical reflective practice. London: David Fulton.

Grimmett, P., Mackinnon, A., Erickson, G., \& Riecken, T. (1990). Reflective practice in teacher education. In R. Clift, W. Houston and M. Pugach (Eds.). Encouraging reflective practice in education: an analysis of issues and programs, NY: Teachers College Press.

Grushka, K., Hinde-McLeod, J., \& Reynolds, R. (2005). Reflecting upon reflection: theory and practice in one Australian university teacher education program. Reflective Practice, 6 (1), 239-246.

Habermas, J. (1971). Knowledge and Human Interests. (J. Shapiro, Trans.). London: Heinemann.

Hatton, N., \& Smith, D. (1995). Reflection in teacher education: Towards definition and Implementation. Teaching and Teacher Education, 11 (1), 33-49. http://dx.doi.org/ 10.1016/0742-051X(94)00012-U

Jakubè, A., \& Juozaitis, A. (2012). Bendruju kompetenciju ugdymas aukštojoje mokykloje. Vilnius: Vilniaus universitetas.

Jay, J., \& Johnson, K. (2002). Capturing complexity: a typology of reflective practice for teacher education. Teaching and Teacher Education, 18, 73-85.

Killion, J., \& Todnem, G. (1991). A process for personal theory building. Educational Leadership, 48 (7), 14-16.

King, P., \& Kitchener, K. (1994). Developing Reflective Judgement. San Francisco, CA: Jossey Bass.

Kolb, D. (1984). Experiential Learning as the Science of Learning and Development. Englewood Cliffs, NJ: Prentice Hall.

Korthagen, F. A. J. (1985). Reflective teaching and preservice teacher education in the Netherlands. Journal of Teacher Education, 36 (5), 11-15.

Korthagen, F., \& Vasalos, A. (2005). Levels in reflection: core reflection as a means to enhance professional growth. Teachers and Teaching: Theory and Practice, 11 (1), 47-71.

Landau, V. (2001). Developing an effective online course. California: California Community Colleges.

Moon, J. (1999). Reflection in Learning and Professional Development. London: Kogan Page.

LaBoskey, V. K. (1994). Development of reflective practice: a study of preservice teachers. New York, NY, London: Teachers College Press.

Larrivee, B. (2008). Development of a Tool to Assess Teachers' Level of Reflective Practice. Reflective Practice, 9, 341-360. http://dx.doi.org/10.1080/14623940802207451.

Lea, S. J., Stephenson, D., \& Troy, J. (2003). Higher education students' attitudes to student centered learning: Beyond 'educational bulimia'. Studies in Higher Education, 28 (3), $321-334$. 
Lee, H. J. (2000). The nature of changes in reflective thinking in preservice mathematics teachers engaged in student teaching field experience in Korea. Paper presented at the Annual Meeting of the American Educational Research Association (AERA), New Orleans, LA, April, 24-28.

Liu, K. (2015). Critical reflection as a framework for transformative learning in teacher education. Educational Review, 67 (2), 135-157. doi:10.1080/00131911.2013.839546

Mezirow, J. (1991). Transformative Dimensions of Adult Learning. San Francisco, CA: JosseyBass.

Rodgers, C. (2002). Defining reflection: Another look at John Dewey and reflective thinking. Teachers College Record, 104 (4), 842-866. http://dx.doi.org/10.1111/1467-9620.0018

Rodgers, C., \& LaBoskey, V. K. (2016). Reflective practice. In J. Loughran, \& M. L. Hamilton (Eds.), International handbook of teacher education (pp. 71-104). DOI 10.1007/978-98110-0369-1_3.

Ross, D. D. (1990). Programmatic structures for the preparation of reflective teachers. In R. T. Clift, W. R. Houston, \& M. C. Pugach (Eds.). Encouraging reflective practice in education (pp. 97-118). New York: Teacher's College Press.

Schon, D. (1983). The Reflective Practitioner: how professionals think in action. New York, NY: Basic Books.

Smith, T. J. (2003). Connecting Theory and Reflective Practice through the Use of Personal Theories. Paper presented at the 27th International Group for the Psychology of Mathematics Education Conference Held Jointly with the 25th PME-NA Conference (Honolulu, HI, Jul 13-18, 2003), v4, pp. 215-222. Retrieved from https://eric.ed.gov/?id=ED501125

Sparks-Langer, G., \& Colton, A. (1991). Synthesis of Research on Teachers' Reflective Thinking. Educational Leadership, March, 37-44.

Taylor, D. (2010). The literature review: A few tips on conducting it. Retrieved from http://www.writing.utoronto.ca/advice/specific-types-of-writing/literature-review

Thorsen, C., \& DeVore, S. (2012). Analyzing Reflection On/For Action: A New Approach. Reflective Practice: International and Multidisciplinary Perspectives, 1-16. doi:10.1080/14623943.2012.732948.

Valli, L. (1990). The question of quality and content in reflective teaching. Paper presented at the annual meeting of the American Educational Research Association, Boston, MA: AERA.

Valli, L. (1997). Listening to other voices: A description of teacher reflection in the United States. Peabody Journal of Education, 72 (1), 67-88.

Van Manen, M. (1977). Linking ways of knowing with ways of being practical. Curriculum Inquiry, 6, 205-228.

Zeichner, K., \& Liston, D. (1996). Reflective Teaching: An Introduction. Mahwah, New Jersey, NJ: Lawrence Erlbaum Associates.

Zwozdiak-Myers, P. (2009). An analysis of the concept reflective practice and an investigation into the development of student teachers' reflective practice within the context of action research. (Doctoral dissertation). Retrieved from vscheiner.brunel.ac.uk/bitstream/ 2438/4316/1/FulltextThesis.pdf 